\title{
Regulation of Pipernonaline on Biological Functions of Human Prostate Cancer Cells Based on Microarray Analysis
}

\author{
Sang-Hun Kim', Kwang-Youn Kim', Sun-Nyoung Yu', Seul-Ki Park', In-Seok Kwak², Moon-Soo Rhee ${ }^{3}$, \\ Byung-Ho Bang ${ }^{4}$, Sung-Sik Chun ${ }^{5}$ and Soon-Cheol Ahn ${ }^{1}$ * \\ ${ }^{1}$ Department of Microbiology and Immunology, Pusan National University School of Medicine, Yangsan 626-870, Korea \\ ${ }^{2}$ Department of Biological Sciences, Silla University Medicine, Busan 617-736, Korea \\ ${ }^{3}$ Korea Research Institute of Bioscience and Biotechnology, Dajean 305-806, Korea \\ ${ }^{4}$ Department of Food and Nutrition Science, College of Health Industry Eulji University, Seongnam 461-713, Korea \\ ${ }^{5}$ Department of Food Science, International University of Korea, Jinju 660-759, Korea
}

Received October 30, 2012 /Revised November 22, 2012 / Accepted November 22, 2012

\begin{abstract}
It has been reported that pipernonaline isolated from Piper longum Linn. has a wide biochemical and pharmacological effect, including antitumor activity in prostate cancer PC-3 cells. However, its mechanism and expression pattern of many genes involved in biological functions are not clearly understood. To perform the gene expression study in PC-3 cells treated with pipernonaline, a cDNA microarray chip composed of 44,000 human cDNA probes was used. As a result, cell cycle-related genes, apoptosis-related genes, and cell proliferation/growth-related genes have been identified in gene ontology of the DAVID database. These results suggest that pipernonaline has antitumor activity by regulating the expression pattern of genes involved in biological signaling pathway in prostate cancer PC-3 cells. Further, additional analysis of these microarray data can be a useful tool to identify the mechanism and discovery of novel genes in cancer therapy.
\end{abstract}

Key words : Pipernonaline, PC-3 cells, microarray, expression, cell cycle, apoptosis, proliferation

\section{서 론}

미국 암 협회의 보고에 따르면 전립선 암은 미국의 남성에 게서 발병하는 암 중 가장 발병률이 높고, 암 관련 사망률 2위 를 나타내고 있다[1]. 우리나라의 경우도 서구화 된 식습관과 생활습관의 변화 및 고령화로 인해 발병률이 빠르게 증가하는 추세이다. 또한, 전립선암은 유전적 요인, 노화, 고지방 식이 등에 따라 발병할 수 있다고 알려져 있으나 정확한 메커니즘 은 밝혀져 있지 않다[8]. 이에 대해 최근에는 천연물을 이용한 생물학적 및 화학적 치료요법을 이용하여 전립선 암세포의 사멸을 유도하는 연구가 많이 이루어지고 있다[2,9]. 본 연구에 사용된 pipernonaline은 후추나무과에 속하는 필발(Piper longum Linn.)에서 분리된 piperine의 유도체로서 전립선 암세포 에서 세포독성 효과와 세포주기 중 G1기를 정지시킴으로써 항암효과를 나타내는 물질이다[3].

본 연구에서 사용된 microarray 분석은 동시에 수 만개 이 상의 유전자 발현양상을 관찰할 수 있는 기술로서 특정 질병 의 유전학적 특성과 기전 연구를 더 광범위하게 연구 할 수 있는 기술이다. 목표로 하는 세포에서 mRNA를 분리하여 형 광물질을 첨가하여 단일 가닥 형태의 cDNA로 합성시켜, 여기

\section{*Corresponding author}

Tel : +82-51-510-8092, Fax : +82-55-382-8090

E-mail : ahnsc@pusan.ac.kr
에 microarray chip에 내장되어있는 probe를 이용하여 발산하 는 형광을 검출하여 발현 변화 양상을 파악할 수 있다[7]. Microarray 분석 후, 얻어지는 많은 정보를 처리하기 위해 새 로운 생물정보학 기술과 통계학적 처리 방법이 요구되는 가운 데, 일반적으로 microarray의 결과는 DAVID database에서 진 핵세포의 유전자 정보를 담고 있는 gene ontology 분석을 통 해 확인 할 수 있다[4,5]. Gene ontology에는 Biological Process, Molecular Function, Cellular Component 등의 ontology가 존재한다[6]. 현재까지 pipernonaline이 전립선 암세 포에서 일어나는 유전자 발현 변화 연구는 아직 미비한 상태 이다. 본 연구에서는 전립선 암세포에 pipernonaline을 처리하 여 cDNA microarray를 실시한 후 DAVID database를 기반으 로 하여 생물학적 과정 중에서 세포주기, 세포사멸, 세포 증식 과 성장을 clustering하여 유전자의 발현 변화를 확인하여 이 후, 전립선암의 치료와 예방에 기여하고자 한다.

\section{재료 및 방법}

\section{재료 및 세포배양}

본 실험에 사용된 pipernonaline은 우리의 이전 연구에서 분리한 시료를 사용하였다[5]. RNA 분리를 위한 RiboEx_column ${ }^{\mathrm{TM}}$ kit는 GeneAll Biotechology Co. (Seoul, Korea)에서 구입하였다. 인간 전립선 암세포주인 PC-3 세포는 
(A)

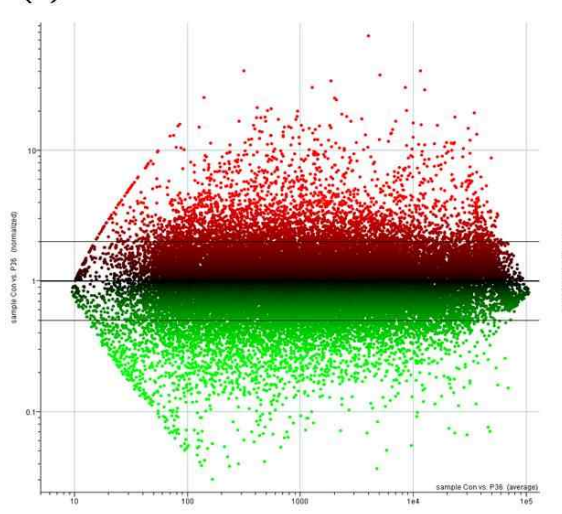

(B)

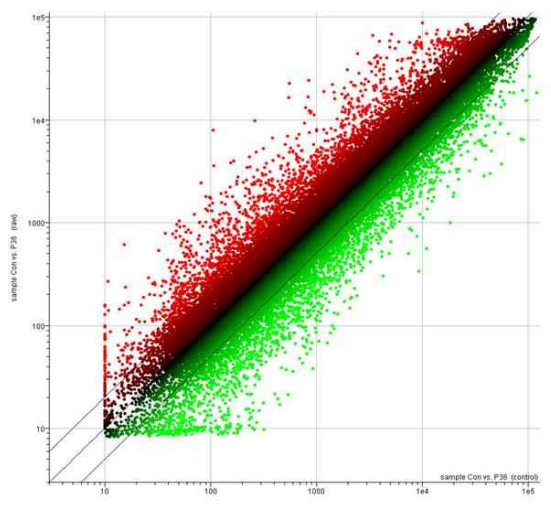

(C)

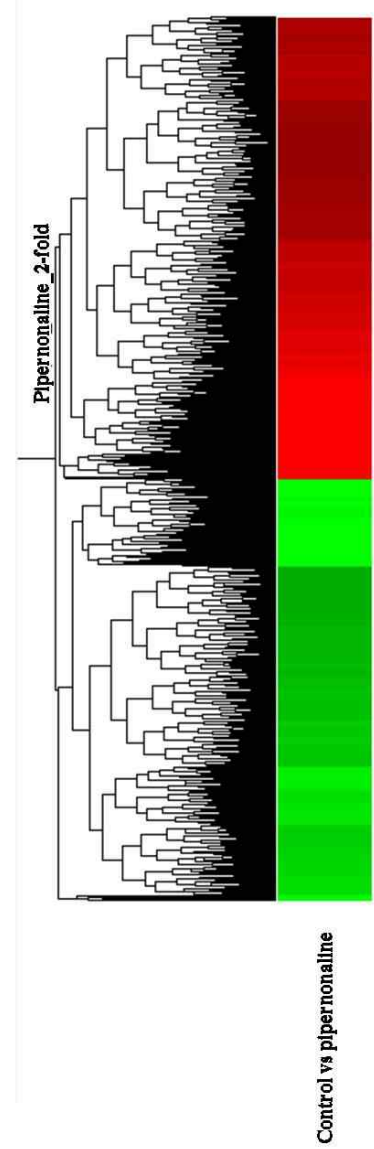

Fig. 1. Visualization of clustered microarray data. (A) MA plot (B) Scatter plot (C) Hierarchical clustering analyses of 5,948 selected genes. The red color refers to the up-regulation of the gene expression and the green color indicated the down-regulation of the gene expression compared with the non-treated pipernonaline.

American Type Culture Collection (ATCC, Manassas, VA, USA)로부터 분양 받아 $10 \%$ fetal bovine serum (WelGene Inc., Daegu, Korea), 100 unit/ml penicillin, $100 \mu \mathrm{g} / \mathrm{ml}$ streptomycin (WelGene Inc.)이 첨가된 DMEM 배지 (WelGene Inc.)에서 $37^{\circ} \mathrm{C}, 5 \% \mathrm{CO}_{2}$ 조건에서 배양하였다. 본 연구는 cell culture dish에 세포가 70-80\% confluent 되었을 때 $30 \mu \mathrm{g} / \mathrm{ml}$ pipernonaline을 24시간 처리하여 실험을 진행하였다.

\section{Total RNA 분리}

Total RNA는 RboEx_column ${ }^{\mathrm{TM}}$ kit를 사용하여 분리하였 다. 간략히, PC-3 세포를 $1 \times 10^{5}$ 되도록 6 well cell culture plate 에 분주하고 24 시간 동안 안정화시킨 후, $30 \mu \mathrm{g} / \mathrm{ml}$ pipernonaline을 24시간 처리하여 배양한 뒤, $1 \mathrm{ml}$ RiboEx reagent를 사용하여 harvest하여 이후, 제조사의 protocol에 따라 RNA 를 분리하였다.

Microarray 실험 및 데이터 분석

Microarray 실험은 GenomicTree, Inc. (Daejeon, Korea)
에 위탁하여 수행하였다. 간략히, cDNA microarray chip은 Agilent Technologies Inc.의 Human whole genome $44 \mathrm{~K}$ (Santa Clara, CA, USA) 사용하였다. 분리한 RNA는 Agilent's 2100 Bioanalyzer System (Agilent Technologies Inc.)을 이용하여 total RNA의 quality를 측정하였고, RNA 의 증폭과 labeling 과정을 위해 Agilent's Low RNA Input Linear Amplification kit PLUS (Agilent Technologies Inc.) 를 이용하였다. Microarray hybridization을 위해 Agilent's Gene Expression Hybridization kit (Agilent Technologies Inc.)를 사용하였고, Agilent's Gene Expression Wash Buffer Kit (Agilent Technologies Inc.)를 이용하여 세척한 후, Agilent's DNA microarray scanner 및 Feature Extraction Software를 이용하여 영상을 스캔하고 분석하였다. Agilent's GeneSpring Software를 이용하여 normalization 및 clustering 통해 유전자의 발현 분석을 하였다. 이후 유전자의 생물 학적, 분자학적 기능을 분류하기 위해서 DAVID database (http://david.abcc.ncifcrf.gov/)를 이용하여 clustering하였다. 


\section{결과 및 고찰}

Microarray를 통한 pipernonaline 처리에 따른 유전자의 변화 확인

사람의 유전자 44,000개를 인지할 수 있는 probe들이 포함 된 Agilent Human whole genome 4 X 44K Chip을 사용하였 다. Normalization 및 clustering을 위해 Agilent's GeneSpring software을 이용하여 MA plot 및 Scatter plot을 측정하여 표 준화하여 각종 변이 등에 의한 오차를 최소한으로 줄였다(Fig. $1 \mathrm{~A}, \mathrm{~B})$. 보정된 유전자 발현 결과는 각 시료 간에 비교 분석 후, 2 배 이상 유의하게 증가 혹은 감소된 값을 가지는 유전자 를 분석하여 significant genes로 적용하였다. 그 결과, 2 배 이 상 유의성 있게 발현이 증가한 유전자의 수는 3,106 개이고, 2 배 이하로 유의성 있게 발현이 감소한 유전자의 수는 2,842 개 였다. significant genes, 총 5,948개에 대하여 hierarchical clustering을 진행한 결과, pipernonaline을 처리함에 따라 2 배 이
상 증가된 유전자(red color)와 2배 이상 감소된 유전자(green color) 발현양상을 확인할 수 있었다(Fig. 1C).

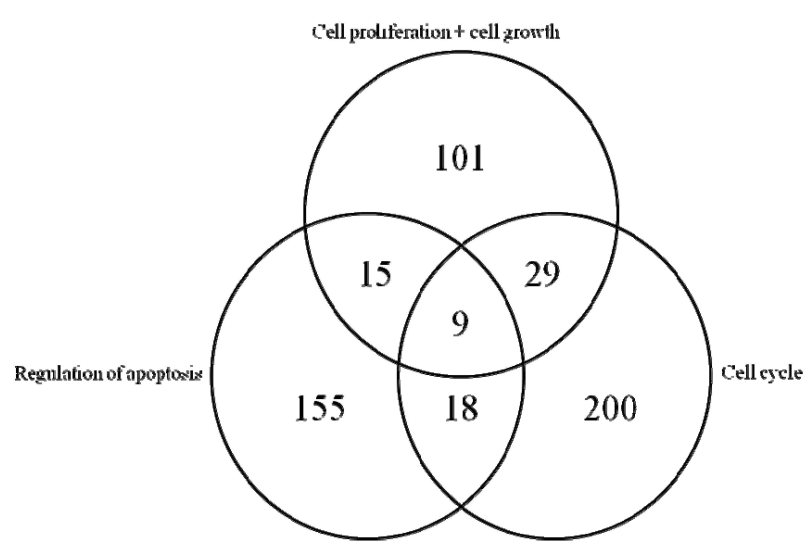

Fig. 2. The number of genes common in any two or all three clustering depicted in the intersections of the circles.

Table 1. Ontological clustering of DAVID database in PC-3 cells after pipernonaline treatment

\begin{tabular}{lcccccc}
\hline Term & Count & 2-fold up & 2-fold down & P-Value & Benjamini & FDR \\
\hline GO:0007049 cell cycle & 256 & 67 & 189 & $2.01 \mathrm{E}-19$ & $1.01 \mathrm{E}-15$ & $3.82 \mathrm{E}-16$ \\
GO:0042981 regulation of apoptosis & 197 & 115 & 82 & $4.94 \mathrm{E}-04$ & 0.05 & 0.94 \\
GO 0008283 ll lif tiGO:0008283 cell proliferation & 108 & 50 & 58 & 0.01 & 0.28 & 12.53 \\
GO:0001558 regulation of cell growth & 50 & 29 & 21 & 0.03 & 0.53 & 48.26 \\
\hline
\end{tabular}

Table 2. Overlapping gene lists in cell proliferation/growth and apoptosis from clustered microarray data Cell proliferation/growth and apoptosis

\begin{tabular}{|c|c|c|c|c|c|c|c|}
\hline $\begin{array}{l}\text { Gene } \\
\text { Symbol }\end{array}$ & Description & Genbank & $\begin{array}{l}\text { Flod } \\
\text { Change }\end{array}$ & $\begin{array}{l}\text { Gene } \\
\text { Symbol }\end{array}$ & Description & Genbank & $\begin{array}{l}\text { Flod } \\
\text { Change }\end{array}$ \\
\hline IGFBP3 & $\begin{array}{l}\text { insulin-like growth factor binding pro- } \\
\text { tein } 3\end{array}$ & NM_001013398 & 13.98 & ACVR1B & activin A receptor, type IB & NM_004302 & 2.79 \\
\hline TP73L & tumor protein $\mathrm{p} 73$-like & NM_003722 & 10.00 & CRYAB & crystallin, alpha B & NM_001885 & 2.49 \\
\hline CDKN1A & $\begin{array}{l}\text { cyclin-dependent kinase inhibitor } 1 \mathrm{~A} \\
\text { (p21, Cip1) }\end{array}$ & NM_000389 & 8.89 & PSEN1 & presenilin 1 (Alzheimer disease 3) & NM_000021 & 2.21 \\
\hline BTG1 & $\begin{array}{l}\text { B-cell translocation gene 1, anti-pro- } \\
\text { liferative }\end{array}$ & NM_001731 & 6.74 & IHPK2 & inositol hexaphosphate kinase 2 & NM_016291 & -2.15 \\
\hline VEGFA & vascular endothelial growth factor A & NM_001025366 & 5.55 & TAF9B & $\begin{array}{l}\text { TAF9B RNA polymerase II, TATA } \\
\text { box binding protein (TBP)-associated } \\
\text { factor, } 31 \mathrm{kDa}\end{array}$ & NM_015975 & -2.16 \\
\hline PIM1 & pim-1 oncogene & NM_002648 & 5.20 & & $\begin{array}{l}\text { sterile alpha motif and leucine zipper } \\
\text { containing kinase AZK }\end{array}$ & NM_016653 & -2.19 \\
\hline IFI16 & interferon, gamma-inducible protein 16 & NM_005531 & 4.64 & BAD & BCL2-antagonist of cell death & NM_004322 & -2.42 \\
\hline APBB2 & $\begin{array}{l}\text { amyloid beta (A4) precursor pro- } \\
\text { tein-binding, family } \mathrm{B} \text {, member } 2 \\
\text { (Fe65-like) }\end{array}$ & NM_173075 & 3.49 & IGF2 & $\begin{array}{l}\text { insulin-like growth factor } 2 \\
\text { (somatomedin A) }\end{array}$ & NM_000612 & -2.51 \\
\hline ADAM17 & $\begin{array}{l}\text { ADAM metallopeptidase domain } 17 \\
\text { (tumor necrosis factor, alpha, convert- } \\
\text { ing enzyme) }\end{array}$ & NM_003183 & 3.29 & PML & promyelocytic leukemia & NM_002675 & -2.54 \\
\hline BCL2L2 & BCL2-like 2 & NM_004050 & 3.06 & HELLS & helicase, lymphoid-specific & NM_018063 & -3.66 \\
\hline HMOX1 & heme oxygenase (decycling) 1 & NM_002133 & 2.87 & CDKN2C & $\begin{array}{l}\text { cyclin-dependent kinase inhibitor } 2 \mathrm{C} \\
\text { (p18, inhibits CDK4) }\end{array}$ & NM_078626 & -5.22 \\
\hline TNFSF14 & $\begin{array}{l}\text { tumor necrosis factor (ligand) super- } \\
\text { family, member } 14\end{array}$ & NM_003807 & 2.83 & IL7 & interleukin 7 & NM_000880 & -5.49 \\
\hline
\end{tabular}


DAVID database (http://david.abcc.ncifcrf.gov/) 를 이용한 gene clustering

2 배 이상 유의하게 증가 혹은 감소된 값을 가지는 유전자를 분석하여 significant genes로 적용한 5,948개의 유전자를 대상 으로 하여 추가 분석을 실시하였다. DAVID database를 이용 하여 GenBank accession number를 입력하였고, 그 중 사람의 유전자 3,941 개와 알려지지 않은 유전자 1,536 개로 분리하여 분석하였다. 먼저 사람의 유전자 3,941개를 functional annotation tool을 이용하여 gene ontology에서 Biological Process로 clustering을 한 결과, 3,785 개의 유전자를 분리하였고, 482 개 의 cluster를 분석하였다(data not shown). 분석한 결과, cel- lular 및 metabolic process에 관련된 유전자들을 많이 포함하 고 있었으며, 특히 세포사멸과 세포주기 관련 및 세포성장 및 증식에 관련된 유전자들을 우선적으로 분석하였다(Table 1). 세포주기에 관련되는 유전자는 256개, 세포사멸에 관련된 유 전자는 197개, 세포성장 및 증식에 관련된 유전자들은 154 개 로 확인되었으며, 이들의 교집합을 이루는 유전자를 각각 분 석하였다(Fig. 2, Table 2-4).

\section{세포주기와 세포사멸, 세포증식 및 성장 관련 유전자 분석}

Gene clustering을 한 결과, 세포주기와 관련한 cluster에서 는 2 배 이상 감소된 유전자가 189 개로 2 배 이상 증가된 유전자

Table 3. Overlapping gene lists in cell proliferation/growth and cell cycle from clustered microarray data Cell proliferation/growth and cell cycle

\begin{tabular}{|c|c|c|c|c|c|c|c|}
\hline $\begin{array}{l}\text { Gene } \\
\text { Symbol }\end{array}$ & Description & Genbank & $\begin{array}{l}\text { Flod } \\
\text { Change }\end{array}$ & $\begin{array}{c}\text { Gene } \\
\text { Symbol }\end{array}$ & Description & Genbank & $\begin{array}{l}\text { Flod } \\
\text { Change }\end{array}$ \\
\hline CDKN1A & $\begin{array}{l}\text { cyclin-dependent kinase inhibitor } \\
\text { 1A (p21, Cip1) }\end{array}$ & NM_OO & 8.89 & MCM7 & $\begin{array}{l}\text { minichromosome maintenance com- } \\
\text { plex component } 7\end{array}$ & 2776 & -2.49 \\
\hline PIM1 & pim-1 & NM_002648 & 5.20 & NASP & $\begin{array}{l}\text { nuclear autoantigenic sperm protein } \\
\text { (histone-binding) }\end{array}$ & 72164 & -2.53 \\
\hline APBB2 & $\begin{array}{l}\text { amyloid beta (A4) precursor pro- } \\
\text { tein-binding, family B, member } 2 \\
\text { (Fe65-like) }\end{array}$ & 75 & 3.49 & PML & ocutic loul & 2675 & -2.54 \\
\hline ADAM17 & $\begin{array}{l}\text { ADAM metallopeptidase domain } \\
17 \text { (tumor necrosis factor, alpha, } \\
\text { converting enzyme) }\end{array}$ & NM_003183 & 3.29 & RB1 & $\begin{array}{l}\text { retinoblastoma } 1 \text { (including osteo- } \\
\text { sarcoma) }\end{array}$ & NM_000321 & -2.59 \\
\hline TACC2 & & C010219 & 3.16 & APRIN & $\begin{array}{l}\text { androgen-induced proliferation in- } \\
\text { hibitor }\end{array}$ & NM_015032 & -2.83 \\
\hline ACVR1B & activin $A$ receptor, type $I B$ & 302 & 2.79 & DTYMK & $\begin{array}{l}\text { deoxythymidylate } \\
\text { (thymidylate kinase) }\end{array}$ & NM_012145 & -2.84 \\
\hline CAMK2D & & 2127 & 2.59 & PSRC1 & proline/serine-rich coiled-coil 1 & 32636 & -3.03 \\
\hline CDK7 & $\begin{array}{l}\text { cyclin-dependent kinase } 7 \text { (MO15 } \\
\text { homolog, Xenopus laevis, cdk-acti- } \\
\text { vating kinase) }\end{array}$ & 1799 & 2.26 & TPX2 & $\begin{array}{l}\text { TPX2, microtubule-associated, homo- } \\
\log \text { (Xenopus laevis) }\end{array}$ & JM_012112 & -3.04 \\
\hline CCDC100 & coiled-coil domain & 3223 & 2.26 & UHRF1 & $\begin{array}{l}\text { ing PHD and } \\
1\end{array}$ & 13282 & -3.12 \\
\hline CND3 & & & -2.04 & HELLS & lymphoid-s & 18063 & -3.66 \\
\hline RACGAP1P & tivating protein 1 & & -2.05 & ASPM & $\begin{array}{l}\text { asp (abnormal spindle) homolog, mi- } \\
\text { crocephaly associated (Drosophila) }\end{array}$ & 18136 & -3.72 \\
\hline FOXM1 & forkhead box M1 & NM_202002 & -2.09 & CUZD1 & $\begin{array}{l}\text { CUB and zona pellucida-like do- } \\
\text { mains } 1\end{array}$ & NM_022034 & -3.93 \\
\hline \multirow[t]{2}{*}{ BUB1 } & ben- & 4336 & -2.09 & POLA1 & polymerase (DNA directed), alpha 1 & TM_016937 & -4.25 \\
\hline & $\begin{array}{l}\text { sterile alpha motif and leucine zip- } \\
\text { per containing kinase AZK }\end{array}$ & JM_016653 & -2.19 & E2F8 & E2F transcription factor 8 & NM_024680 & -4.34 \\
\hline ING1 & $\begin{array}{l}\text { inhibitor of growth family, member } \\
1\end{array}$ & 13 & -2.30 & TACC3 & $\begin{array}{l}\text { transforming, acidic coiled-coil con- } \\
\text { taining protein } 3\end{array}$ & NM_006342 & -4.58 \\
\hline CKS1B & $\begin{array}{l}\text { CDC28 protein kinase regulatory } \\
\text { subunit } 1 \mathrm{~B}\end{array}$ & M_001826 & -2.37 & CDC25A & $\begin{array}{l}\text { cell division cycle } 25 \text { homolog A } \\
\text { (S. pombe) }\end{array}$ & NM_001789 & -4.99 \\
\hline PES1 & $\begin{array}{l}\text { pescadillo homolog 1, containing } \\
\text { BRCT domain (zebrafish) }\end{array}$ & M_014303 & -2.38 & $\mathrm{CDKN} 2 \mathrm{C}$ & $\begin{array}{l}\text { cyclin-dependent kinase inhibitor } 2 \mathrm{C} \\
\text { (p18, inhibits CDK4) }\end{array}$ & NM_078626 & -5.22 \\
\hline BUB1B & $\begin{array}{l}\text { BUB1 budding uninhibited by ben- } \\
\text { zimidazoles } 1 \text { homolog beta (yeast) }\end{array}$ & JM_001211 & -2.41 & CENPF & $\begin{array}{l}\text { centromere protein } \mathrm{F}, 350 / 400 \mathrm{ka} \\
\text { (mitosin) }\end{array}$ & NM_016343 & -5.35 \\
\hline NDE1 & $\begin{array}{l}\text { nudE nuclear distribution gene } \mathrm{E} \\
\text { homolog } 1 \text { (A. nidulans) }\end{array}$ & 668 & -2.48 & KIF15 & kinesin family member 15 & NM_020242 & -5.72 \\
\hline
\end{tabular}


67개보다 더 많이 확인되었다. 특히, 세포주기를 촉진하는 cyclins과 cyclin-dependent kinases (CDKs) 유전자 같은 경우 전체적으로 발현이 감소 되었고, 대표적인 세포주기 억제 단 백질 $\mathrm{CDK}$ inhibitor $1 \mathrm{~A}$ (p21)인 CDKN1A는 8배 이상 증가를 확인함으로써, pipernonaline이 세포주기를 활성화 시키는 유 전자의 발현감소 또는 억제 유전자의 발현 증가를 유도함으로
써 세포주기에 영향을 미치는 것을 알 수 있었다. 세포사멸과 관련된 cluster의 경우, 2 배 이상 감소된 유전자보다 2 배 이상 증가된 유전자가 더 많이 나타났으며 세포사멸과 관련된 대표 적인 유전자 중, caspase family와 Bcl-2 family, tumor necrosis factor 등의 발현 변화를 확인하였다. 세포증식 및 성장 에 관련된 cluster에서는 성장 인자인 insulin-like growth fac-

Table 4. Overlapping gene lists in apoptosis and cell cycle from clustered microarray data Apoptosis and cell cycle

\begin{tabular}{|c|c|c|c|c|c|c|c|}
\hline $\begin{array}{c}\text { Gene } \\
\text { Symbol }\end{array}$ & Description & Genbank & $\begin{array}{c}\text { Flod } \\
\text { Change }\end{array}$ & $\begin{array}{c}\text { Gene } \\
\text { Symbol }\end{array}$ & Description & Genbank & $\begin{array}{c}\text { Flod } \\
\text { Change }\end{array}$ \\
\hline CDKN1A & $\begin{array}{l}\text { cyclin-dependent kinase inhibitor 1A } \\
\text { (p21, Cip1) }\end{array}$ & NM_000389 & 8.89 & ABL1 & $\begin{array}{l}\text { v-abl Abelson murine leukemia } \\
\text { viral oncogene homolog } 1\end{array}$ & NM_005157 & -2.12 \\
\hline ARHGEF2 & $\begin{array}{l}\text { rho/rac guanine nucleotide exchange } \\
\text { factor (GEF) } 2\end{array}$ & IM_004723 & 6.41 & DNM2 & dynamin 2 & NM_001005360 & -2.18 \\
\hline DDIT3 & DNA-damage-inducible transcript 3 & NM_004083 & 6.32 & & $\begin{array}{l}\text { sterile alpha motif and leucine } \\
\text { zipper containing kinase AZK }\end{array}$ & NM_016653 & -2.19 \\
\hline DUSP1 & dual specificity phosphatase 1 & M_004417 & 5.63 & BRCA1 & breast cancer 1 , early onset & NM_007295 & -2.25 \\
\hline PIM1 & pim-1 oncogene & NM_002648 & 5.20 & MAEA & $\begin{array}{l}\text { macrophage erythroblast at- } \\
\text { tacher }\end{array}$ & NM_001017405 & -2.45 \\
\hline APBB2 & $\begin{array}{l}\text { amyloid beta (A4) precursor protein-bind- } \\
\text { ing, family B, member } 2 \text { (Fe65-like) }\end{array}$ & M_173075 & 3.49 & PML & promyelocytic leukemia & NM_002675 & -2.54 \\
\hline \multirow[t]{2}{*}{ ADAM17 } & $\begin{array}{l}\text { ADAM metallopeptidase domain } 17 \\
\text { (tumor necrosis factor, alpha, convert- } \\
\text { ing enzyme) }\end{array}$ & NM_003183 & 3.29 & PSME3 & $\begin{array}{l}\text { proteasome (prosome, macro- } \\
\text { pain) activator subunit } 3 \text { (PA28 } \\
\text { gamma; Ki) }\end{array}$ & NM_005789 & -2.59 \\
\hline & $\begin{array}{l}\text { junction-mediating and regulatory } \\
\text { protein }\end{array}$ & NM_152405 & 2.87 & $\mathrm{MSH} 2$ & $\begin{array}{l}\text { mutS homolog 2, colon cancer, } \\
\text { nonpolyposis type } 1 \text { (E. coll) }\end{array}$ & NM_000251 & -3.16 \\
\hline ACVR1B & activin $\mathrm{A}$ receptor, type IB & NM_004302 & 2.79 & HELLS & helicase, lymphoid-specific & NM_018063 & -3.66 \\
\hline RB1CC1 & RB1-inducible coiled-coil 1 & NM_014781 & 2.70 & MAP2К6 & $\begin{array}{l}\text { mitogen-activated protein kin- } \\
\text { ase kinase } 6\end{array}$ & NM_002758 & -4.02 \\
\hline GSK3B & glycogen synthase kinase 3 beta & NM_002093 & 2.60 & CDC2 & $\begin{array}{l}\text { cell division cycle 2, G1 to } \mathrm{S} \\
\text { and } \mathrm{G} 2 \text { to } \mathrm{M}\end{array}$ & NM_001786 & -4.08 \\
\hline IFNG & interferon, gamma & NM_000619 & 2.12 & BARD1 & $\begin{array}{l}\text { BRCA1 associated RING do- } \\
\text { main } 1\end{array}$ & NM_000465 & -4.55 \\
\hline TXNIP & thioredoxin interacting protein & NM_006472 & 2.04 & CDKN2C & $\begin{array}{l}\text { cyclin-dependent kinase in- } \\
\text { hibitor } 2 \mathrm{C} \text { (p18, inhibits CDK4) }\end{array}$ & NM_078626 & -5.22 \\
\hline JAG2 & jagged 2 & NM_002226 & -2.03 & & & & \\
\hline
\end{tabular}

Table 5. Total overlapping gene lists in cell proliferation/growth and cell cycle and apoptosis from clustered microarray data

\begin{tabular}{lllc}
\hline Gene Symbol & Description & Genbank & Fold Change \\
\hline CDKN1A & cyclin-dependent kinase inhibitor 1A (p21, Cip1) & NM_000389 & 8.89 \\
\hline PIM1 & pim-1 oncogene & NM_002648 & 5.20 \\
\hline \multirow{2}{*}{ APBB2 } & $\begin{array}{l}\text { amyloid beta (A4) precursor protein-binding, family B, member 2 } \\
\text { (Fe65-like) }\end{array}$ & NM_173075 & 3.49 \\
\hline \multirow{2}{*}{ ADAM17 } & $\begin{array}{l}\text { ADAM metallopeptidase domain 17 (tumor necrosis factor, alpha, } \\
\text { converting enzyme) }\end{array}$ & NM_003183 & 3.29 \\
\hline ACVR1B & activin A receptor, type IB & NM_004302 & 2.79 \\
\hline CDKN2C & cyclin-dependent kinase inhibitor 2C (p18, inhibits CDK4) & NM_078626 & -5.22 \\
\hline HELLS & helicase, lymphoid-specific & NM_018063 & -3.66 \\
\hline PML & promyelocytic leukemia & NM_002675 & -2.54 \\
\hline & sterile alpha motif and leucine zipper containing kinase AZK & NM_016653 & -2.19 \\
\hline
\end{tabular}


tor와 vascular endothelial growth factor 등 관련 유전자 및 성장 저해 인자인 $\mathrm{CDK}$ inhibitor와 androgen-induced proliferation inhibitor 등 관련 유전자의 발현 변화를 확인하였다. 또한 세포주기, 세포사멸, 세포증식 및 성장에 공통적으로 발 현되는 유전자를 확인한 결과, 대표적인 세포주기 억제 유전 자 $\mathrm{CDKN} 1 \mathrm{~A}$ 가 8배 이상 가장 많이 증가한 반면, $\mathrm{CDK}$ inhibitor 2C (p18)인 CDKN2C는 5배 이상 감소되었다(Table 5). 이러한 결과는 pipernonaline의 처리는 전립선 암세포에 존재 하는 다양한 신호전달 체계에 관여하는 것을 알 수 있으며, 본 연구에서는 $\mathrm{CDKN} 2 \mathrm{C}$ 유전자 발현 감소보다 CDKN1A 유 전자의 발현 증가가 pipernonaline이 처리된 전립선 암세포에 대해 더 우선적으로 작용함으로써 세포의 성장억제를 유도함 을 알 수 있었다. 이상의 이러한 결과들로부터 전립선 암세포 에서 pipernonaline는 세포주기, 세포사멸 그리고 세포증식 및 성장에 관련된 다양한 유전자를 조절함으로써 세포사멸의 유 도, 세포증식과 성장을 저해 하는 것을 알 수 있고, 이러한 microarray의 결과를 바탕으로 in vivo상에서 실제로 암세포의 사멸과 관련된 새로운 유전자 탐색 및 메커니즘을 규명하는데 유용하게 사용할 수 있을 것으로 사료된다.

\section{감사의 글}

본 연구는 2010학년도 부산대학교 교수국외장기파견 지원 비에 의하여 연구되었음.

\section{References}

1. ACS. 2012. Cancer facts \& figures. American cancer society.
2. Eom, K. S., Hong, J. M., Youn, M. J., So, H. S., Park, R., Kim, J. M. and Kim, T. Y. 2008. Berberine induces G1 arrest and apoptosis in human glioblastoma T98G cells through mitochondrial/caspases pathway. Biol. Pharm Bull. 31, 558-562.

3. Kim, K. Y., Kim, Y. J., Lee, W., Yu, S. N., Cho, H. J., Lee, S. Y., Lee, H. S., Sohn, J. H., Oh, H. C. and Ahn, S. C. 2009. Purification and identification of apoptosis modulator pipernonaline from piper longum Linn. against prostate cancer cells. J. Life Sci. 19, 671-675.

4. Lammers, G., Gilissen, C., Nillesen, S. T., Uijtdewilligen, P. J., Wismans, R. G., Veltman, J. A., Daamen, W. F. and van Kuppevelt, T. H. 2010. High density gene expression microarrays and gene ontology analysis for identifying processes in implanted tissue engineering constructs. Biomaterials 31, 8299-8312.

5. Li, S., Becich, M. J. and Gilbertson, J. 2004. Microarray data mining using gene ontology. Stud Health Technol. Inform 107, 778-782.

6. Michael, B. and Lawrence, H. 2008. Identification of OBO nonalignments and its implications for OBO enrichment. Bioinformatics 24, 1448-1455.

7. Nguyen, D. V., Arpat, A. B., Wang, N. and Carroll, R. J. 2002. DNA microarray experiments: Biological and technological aspects. Biometrics 58, 701-717.

8. Park, S. K., Sakoda, L. C., Kang, D., Chokkalingam, A. P., Lee, E., Shin, H. R., Ahn, Y. O., Shin, M. H., Lee, C. W., Lee, D. H., Blair, A., Devesa, S. S. and Hsing, A. W. 2006. Rising prostate cancer rates in South Korea. Prostate 66, 1285-1291.

9. Wang, M., Ruan, Y., Chen, Q., Li, S., Wang, Q. and Cai, J. 2011. Curcumin induced HepG2 cell apoptosis-associated mitochondrial membrane potential and intracellular free $\mathrm{Ca}(2+)$ concentration. Eur. J. Pharmacol. 650, 41-47.

\section{초록 : Microarray를 이용한 pipernonaline의 인간 전립선 암세포에 대한 기능 조절 분석}

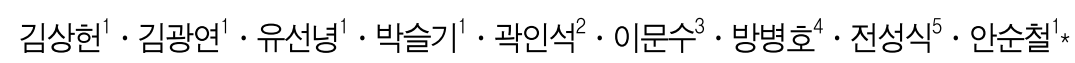

$\left({ }^{1}\right.$ 부산대학교 의학전문대학원 미생물학 및 면역학 교실, ${ }^{2}$ 신라대학교 생물과학과, ${ }^{3}$ 한국생명공학연구원 생명 자원센터, ${ }^{4}$ 을지대학교 보건산업대학 식품영양학과, ${ }^{5}$ 한국국제대학교 식품과학과)

Pipernonaline은 후추나무과에 속하는 필발(Piper longum Linn.)의 유도체로서 전립선 암세포에 대한 항암활성 이 보고되고 있다. 하지만 실제 암세포 내에서 생물학적 정보를 가진 수 많은 유전자들에 대한 발현이 어떻게 이루어지고 있는지 알려진 바가 없다. 본 연구에 사용된 microarray 분석은 동시에 수 만개 이상의 유전자 발현 양상을 한번에 관찰할 수 있는 기술로서 특정 질병의 유전학적 특성과 기전 연구를 더 광범위하게 연구 할 수 있는 기술이다. 본 연구에서는 전립선 암세포인 PC-3 세포에 pipernonaline을 처리하여 cDNA microarray를 실 시하였다. 이후, DAVID database를 이용하여 gene ontology의 Biological Process를 분석하여 세포사멸과 세포주 기, 세포성장 및 증식에 관련된 유전자들을 우선적으로 분석하였다. 그 결과, 세포주기관련 256개, 세포사멸관련 197 개, 세포성장 및 증식관련에 154 개의 유전자가 확인 되었다. 이러한 결과는 pipernonaline은 전립선 암세포 내에 존재하는 생물학적 신호전달체계에 관련된 유전자 발현을 조절함으로써 항암활성을 나타내 것을 알 수 있 었고, 이후 이러한 microarray의 추가적인 분석은 암세포 내 새로운 유전자의 탐색 및 메커니즘을 규명하는데 유용하게 사용할 수 있을 것으로 사료된다. 